\title{
Tree mortality from a short-duration freezing event and global-change-type drought in a Southwestern piñon-juniper woodland, USA
}

This study documents tree mortality in Big Bend National Park in Texas in response to the most acute one-year drought on record, which occurred following a five-day winter freeze. I estimated changes in forest stand structure and species composition due to freezing and drought in the Chisos Mountains of Big Bend National Park using permanent monitoring plot data. The drought killed over half (63\%) of the sampled trees over the entire elevation gradient. Significant mortality occurred in trees up to $20 \mathrm{~cm}$ diameter $(P<0.05)$. Pinus cembroides Zucc. experienced the highest seedling and tree mortality $(P<0.0001)(55 \%$ of piñon pines died), and over five times as many standing dead pines were observed in 2012 than in 2009. Juniperus deppeana vonSteudal and Quercus emoryi Leibmann also experienced significant declines in tree density $(P<0.02)(30.9 \%$ and $20.7 \%$, respectively). Subsequent droughts under climate change will likely cause even greater damage to trees that survived this record drought, especially if such events follow freezes. The results from this study highlight the vulnerability of trees in the Southwest to climatic change and that future shifts in forest structure can have large-scale community consequences. 


\section{1. Introduction}

2 Recent widespread tree mortality has been documented across the globe in response to

3 increasingly warmer and drier climatic conditions (Allen and Breshears, 1998; Breashears et al.,

4 2009; vanMantgem et al., 2009; Allen et al., 2010). Global-change-type droughts, which are

5 severe droughts coupled with elevated summer temperatures, have resulted in landscape- and

6 regional-scale shifts in forest stand structure and species composition (Breshears et al., 2005;

7 Shaw et al., 2005). While multi-year droughts have been widely identified as agents of tree

8 mortality (Guarin and Taylor, 2005; vanMantgem et al., 2009; Ganey and Vojta, 2011), short-

9 duration acute droughts of one to two years in duration can also be responsible for extensive tree

10 death (Breshears et al., 2005; Hogg et al., 2008).

11 Acute drought events that follow short-duration winter freezes can be especially

12 damaging to plant tissue. Tree death can occur under severe drought after just a single, short-

13 duration freezing event (Willson and Jackson, 2006). Rapid changes in temperature present a

14 unique challenge to trees because cold snaps can cause air bubbles and sap ice to form which can

15 result in stem breakage and hinder water transport (Scholander et al., 1961; Hammel, 1967;

16 Sucoff, 1969; Zimmermann, 1983).

A five-day freeze occurred in February 2011 in Big Bend National Park, which was

18 followed by the most severe one-year drought on record in Texas in the spring and summer of

192011 (Neilson-Gammon, 2011) (Figure 1). West Texas was particularly affected by the drought

20 (National Drought Mitigation Center, 2011), and the Chisos Basin of Big Bend National Park

21 received just $10.9 \mathrm{~cm}$ of precipitation in 2011 (one fifth its historical average of $49.2 \mathrm{~cm}$ )

22 (WRCC, 2012). Together, the freeze and drought events were likely responsible for widespread

23 tree mortality between 2011 and 2012 in this region. 
As part of a permanent forest monitoring study in the Chisos Mountains (CM) of Big

25 Bend National Park, I monitored tree mortality in a Southwestern piñon-juniper forest between

262009 and 2012. This interval overlapped the five-day February freezing event and global-change-

27 type acute drought that occurred in 2011, providing the unique opportunity to document a

28 coupled freezing- and drought-induced tree mortality event. While piñon-juniper tree mortality in

29 response to severe drought has been documented in several sites in the southwestern United

30 States, few studies have examined the combined effects of short-duration freezing and acute

31 drought events on piñon-juniper woodland stand structure and species composition. Moreover,

32 this research highlights tree mortality patterns across a post-Pleistocene relictual mountain range

33 (i.e. Sky Island) that differs dramatically from other previously studied piñon-juniper forests in

34 terms of species composition and climatic setting.

In this paper, I quantify tree mortality by estimating changes in forest stand structure and species composition across the forested area of the elevation gradient in Big Bend National Park.

37 I measured changes in live and standing dead tree density, basal area, and species composition in

$38 \mathrm{CM}$ as a whole and at low, middle and high elevations individually. This information provides an 39 assessment of the combined effects of freezing and acute drought stress in Sky Island forests that

40 are surrounded by lowland desert and whose distributions are already greatly restricted by

41 contemporary climatic conditions.

\section{2. Materials and methods}

\section{2.1 Study area}

The Chisos Mountains are a small rhyolitic mountain range located entirely within Big

45 Bend National Park. Current forests are Pleistocene relicts, and their distributions are the product 
46 of species migrations from lowlands to uplands during early Holocene warming (VanDevender

47 and Spaulding, 1979). The CM rise to $2300 \mathrm{~m}$ asl. They are bound at lower elevations by deserts

48 dominated by shrub and succulent desert flora, where tree establishment and growth is inhibited

49 due to high temperatures and moisture-limited conditions. The CM represent an ecological

50 transition zone because of their position at the eastern edge of the Basin and Range Province and

51 they share biological affinities with flora of the Rocky Mountains and the Sierra Madre Ranges

52 (Muldavin, 2002). Soils are a mixture of mollisols and entisols. They are composed of

53 moderately deep gravelly loam, which is well drained and non-calcareous (Carter, 1928). Runoff

54 is moderate to rapid. Available water capacity is low.

Forests (above $1600 \mathrm{~m}$ asl) in CM are composed of piñon-juniper-oak, pine-oak, and mixed conifer woodlands. Piñon-juniper woodland is the dominant forest type which is comprised of Mexican piñon pine (Pinus cembroides Zuccarini), alligator juniper (Juniperus

58 deppeana vonSteudal), gray oak (Quercus grisea Liebmann), Graves oak (Quercus gravesii

59 Sudworth), Emory oak (Q. emoryi Leibmann), and weeping juniper (J. flaccida

60 vonSchlechtendal) (Poulos and Camp, 2010). Lower elevations also contain small populations of

61 one seed juniper (J. monosperma Englemann) and red berry juniper (J. pinchotii Sudworth) and

62 oak shrublands that are dominated by $Q$. pungens Leibmann. Arizona pine (P. arizonica

63 Englemann), Douglas fir (Pseudotsuga menziesii Mirbel), and Arizona cypress (Cupressus

64 arizonica Greene) also have restricted populations in Boot Canyon in CM. Taxonomy follows

65 Powell (1998).

66 The modern climate is arid, characterized by cool winters and warm summers.

67 Precipitation is distributed bi-modally in late summer and winter with the majority of

68 precipitation falling during summer storms as part of the North American Monsoon System.

69 Mean annual precipitation for the Chisos Basin is $49.7 \mathrm{~cm}$ (range $10-135 \mathrm{~cm}$ ). Mean January 
70 precipitation is $1.5 \mathrm{~cm}$ (range $0-2.5 \mathrm{~cm}$ ) and is $8.0 \mathrm{~cm}$ (range $0.2-20.5 \mathrm{~cm}$ ) in July. Mean

71 monthly minimum temperatures are $1.8^{\circ} \mathrm{C}$ in January and $17.0^{\circ} \mathrm{C}$ in July. Maximum

72 temperatures are $14.1^{\circ} \mathrm{C}$ in January and $29.1^{\circ} \mathrm{C}$ in July.

\section{$73 \quad 2.2$ Field sampling}

74 Thirty-six plots were established at low, middle, and high elevations (12 at each elevation)

75 in the CM in June 2009 and I resampled them during the growing season in June 2012 after the

76 drought. Low elevation plots were randomly placed in Green Gulch within $100 \mathrm{~m}$ of the edge of

77 tree cover in CM. Middle elevation plots were randomly distributed across the Chisos Basin.

78 High elevation plots were randomly distributed along the Southeast Rim. Plots were located so

79 that they did not intersect trails, power lines, or archeological or cultural resources. The Southeast

80 Rim was chosen for the high elevation sampling area because it had not previously burned in

81 prescribed fires or wildfires. Trees $>5 \mathrm{~cm}$ diameter at breast height (dbh) were measured using

$8210 \mathrm{~m}$ radius ( $0.03 \mathrm{ha}$ ) fixed area plots. Seedlings (individuals $<5 \mathrm{~cm} \mathrm{dbh}$ ) were tallied by species

83 in nested $5 \mathrm{~m}$ radius plots. Plot boundaries for both the tree and seedling plots were determined

84 using a two-way ultrasonic rangefinder (Cptcam Inc., Shenzhen, China). The center point of each

85 plot was marked with rebar and its location was recorded with a gps. Each tree was tagged with a

86 uniquely numbered brass tree tag in 2009. I recorded the species, dbh, condition (live or standing

87 dead), distance from the plot center and azimuth from north of each individual. Distance and

88 azimuth measurements greatly assisted in relocating plot center. In 2012, plots were revisited and

89 all trees from the 2009 inventory were resampled. Tree condition (live, recent snag, snag broken

90 above dbh, snag broken below dbh, or clean snag) was noted. Trees lacking leaves or needles,

91 with brittle and/or missing branches were classified as recent snags in the 2012 sampling interval. 
92 All recent snags were also checked for evidence of bark beetle infestation including presence of

93 pitch tubes and beetle galleries.

\section{$94 \quad 2.3$ Statistical analysis}

95 I quantified differences in forest stand structure in 2009 and 2012 using linear mixed

96 effects models to account for the repeated measures sampling design. I used the R Statistical

97 Language (․ㅡ Development Core Team 2012) and the lme4 (ㅁates, Mächler et al. 2012) and

98 lmerTest (Kuznetsova, Brockhoff et al. 2013) packages to perform linear mixed effects analyses

99 of the temporal shifts in forest structure and species composition from the freeze and drought

100 events. Timestep was designated as a fixed effect. Random effects were considered for the

101 intercept, the sample plot, and the interaction of sample plot and timestep. The residuals of each

102 model were inspected for deviations from homoscedasticity, and only models containing

103 residuals without obvious deviations from normality were kept in the analysis. The final structure

104 of the fixed-effects for each model was selected by sequentially dropping non-significant terms

105 from the full model, by measuring changes in the significance of conditional F-tests for each term

106 (Pinheiro and Bates 2000). The intra-class correlation was also estimated for each model in order

107 to assess the amount of variance in the response variable that can be attributed to the random

108 effects in a model. The models describing the data most adequately were then selected using the

109 Akaike Information Criterion (AIC) (Akaike 1974). The significance of individual sites and site-

110 year combinations was assessed after final model selection via the F statistic using the lmerTest

111 package.

112 I used plots as the repeated sampling unit and the sampling year as the treatment

113 representing pre- and post-drought sampling intervals. I compared tree basal area, live seedling 
114 and tree density by species, and differences in forest size structure for the two sampling years. I

115 also used mixed effects models to investigate how the drought affected tree populations across

116 the elevation gradient by evaluating changes in tree density and species composition in response

117 to the drought. I evaluated the trend in tree mortality by size by performing a regression analysis

118 comparing the percentage mortality at $1.0 \mathrm{~cm}$ size-class intervals.

\section{3. Results}

The 2011 freeze and drought killed over half (62.9\%) of the trees in the sample plots in

$121 \mathrm{CM}$. The event triggered significant mortality of both seedlings and trees up to $20 \mathrm{~cm} \mathrm{dbh}(P<$

1220.05 ) (Figure 2). Live tree densities decreased by approximately 100 trees $\mathrm{ha}^{-1}$. Seedlings and

123 smaller trees were preferentially affected by the drought, while larger trees generally survived

124 (Figures 2C-D and 3) $\left(R^{2}=0.62 ; F=13.1 ; P=0.0016\right)$. Over half $(59.9 \%)$ of the seedlings in the

125 monitoring plots died between $2009\left(1059 \pm 49.8 \mathrm{ha}^{-1}\right)$ and $2012\left(428.8 \pm 34.7 \mathrm{ha}^{-1}\right)(P=0.002)$.

126 However, basal area also decreased significantly from $12.38 \pm 1.75 \mathrm{~m}^{2} \mathrm{ha}^{-1}$ in 2009 to $8.47 .6 \pm$

$1271.84 \mathrm{~m}^{2} \mathrm{ha}^{-1}(P=0.001)$ in 2012 indicating that some larger tree mortality also occurred. None of

128 the adult trees that died over the sampling interval showed evidence of bark beetle infestation.

129 The freeze and drought resulted in divergent tree mortality patterns among species. Piñon

130 pine experienced the highest seedling and tree mortality $(P<0.0001)$, and over five times as

131 many standing dead piñon pines were observed in 2012 as in 2009 (54.5\% of the piñon pines

132 died). Alligator juniper and Emory oak trees also experienced significant declines in live tree

133 abundance $(P<0.02)(20.7 \%$ and $30.9 \%$ change in tree density, respectively), and alligator

134 juniper, one seeded juniper, and Emory oak similarly experienced significant seedling mortality

$135(P<0.05)$. 
137 mortality was significant across all elevations $(P<0.05)$, and mortality increased with increasing 138 elevation (Figure 4). Piñon pine experienced significantly greater tree mortality at low elevations $139(P=0.007)$, but otherwise tree mortality by species did not vary significantly over the elevation 140 gradient in response to the freeze and drought.

\section{4. Discussion}

Landscape-scale tree mortality occurred in the Chisos Mountains in response to the fiveday February freeze and subsequent global-change-type drought in 2011. The effects of this event spanned the entire mountain range and affected multiple tree species. The tree mortality that occurred in response to this short-duration freezing event and one-year drought is striking

146 because relatively few trees in CM succumbed to the longer decadal drought of the 1990s in this 147 region (Poulos, personal observation).

While the individual effects of the drought and freezing event could not be distinguished

149 from the present study, both freezing- and drought-induced xylem cavitation likely contributed to

150 the CM tree mortality patterns due to air bubble formation from frozen sap at low temperatures

151 (Pittermann et al., 2005; Sperry, 2011) and to the entry of air bubbles into the xylem conduits

152 across the pit membrane under extremely negative water potentials during the drought

153 (Zimmerman, 1983; Sperry and Tyree, 1990). Pittermann et al. (2005) demonstrated

154 experimentally that conifers exposed to freeze-thaw events occurring in concert with drought

155 stress had high cavitation vulnerability relative to conifers experiencing drought alone. Schaberg

156 et al. (2008) also demonstrated that spring warming following winter freeze caused root damage

157 that resulted in almost 100\% seedling mortality in greenhouse experiments on Alaskan yellow 
158

159

160

161 junipers could experience xylem embolism from just a single freeze-thaw cycle when under

162 drought stress. While the drought may have been responsible for most of the tree mortality

163 observed between 2009 and 2012, the visible branch splitting and bark heaving on many CM

164 trees after the freeze (Poulos, personal observation) indicated that low temperatures during the 165 winter of 2011 could have also contributed to tree death.

\subsection{Preferential mortality of small trees}

With increasing tree size, mortality rate commonly decreases (Lorimer et al., 2001; Palahi

et al., 2003). The pattern of higher mortality of smaller trees in CM was consistent with the recent

169 die off event of Pinus edulis between 2002 and 2004 Arizona, New Mexico, Colorado, and Utah,

170 although Mueller et al. (2005) observed the opposite pattern during the 1996 and 2002 acute

171 droughts in piñon-juniper woodlands of northern Arizona. My results in the CM were consistent

172 with the trend of high seedling and sapling mortality under drought relative to larger trees that,

173 with their deeper root systems and larger carbon stores, were able to survive those same drought

174 events (Mendel et al., 1997; Mueller et al., 2005; Lopez and Kursar, 2007, Ganey and Vojta

175 2011). The lack of evidence of bark beetle infestation in trees that died over the sampling interval

176 also suggests that the high mortality of small-diameter trees was not related to insect attack.

\subsection{Differential tree mortality by species}


179 the increased mortality of piñon pine relative to other tree species was consistent with the patterns

180 of recent mass tree mortality in the Southwest in 1996 and 2002 where piñon pine was more

181 severely affected by drought than juniper (Mueller et al., 2005; Breshears et al., 2009). Junipers

182 are typically more drought tolerant than pines in the American Southwest (Breshears et al., 2009;

183 McDowell et al., 2008 but see Bowker et al., 2012). So while junipers in CM did experience

184 significant mortality from the 2011 drought, they were probably less affected than the piñon pines 185 because of their higher drought hardiness.

186 Emory oak was also significantly affected by the drought, and large stands of this species

187 were completely killed in CM. Although southwestern oaks can survive over two months of

188 severe moisture stress under experimental conditions (Poulos et al., 2007; Ehleringer and Phillips,

189 1996), little is known about the mechanisms of oak drought and freezing tolerance in the

190 American Southwest (but see Neilson and Wullstein, 1985; Davis et al., 1999). Oaks in this

191 region likely display considerable variation in drought and freezing tolerance, but their large

192 tracheid diameters may have led to greater freeze-induced cavitation vulnerability relative to

193 other tree species (Davis et al., 1999). Emory oaks experienced lower mortality than piñon pines

194 and junipers in this study, yet, there remains a need for more information about the range of

195 variability in oak drought tolerance mechanisms in the Southwest as they represent a major

196 component of Madrean Sky Island systems.

\subsection{Shifts in forest stand structure and species composition}

Although the mortality event will undoubtedly provide new nesting sites for cavity-

199 nesting birds in CM, the higher mortality of smaller trees, the loss of over half of the piñon pines 
in my monitoring plots, and the death of piñon pine and entire stands of Emory oak across all

201 elevations could result in major shifts in forest stand structure and species composition. Since

202 2011, CM has moved out of the drought and is experiencing normal temperature and precipitation

203 levels. The return to normal climatic conditions could have a positive effect on surviving trees by

204 releasing them from competition for moisture and bolstering their survival potential in

205 subsequent droughts (Bowker et al., 2012) since water use efficiency in piñon-juniper woodlands

206 can be associated with stand density (Lajtha and Getz, 1993). Nonetheless, surviving trees in CM

207 may have experienced permanent losses in xylem conductivity in 2011, which could result in

208 delayed tree mortaility (i.e. Bigler et al., 2007) or predispose them to succumb to future acute

209 droughts, especially if these events are coupled with winter freezes. While many piñon pines

210 survived the 2011 drought, future global-change-type droughts could shift CM species towards

211 dominance by junipers and more drought-tolerant oaks.

\subsection{Mortality patterns across the elevation gradient}

The pattern of increased tree mortality with increasing elevation was surprising and

and Breshears, 1998; Gitlin et al., 2006; McDowell et al., 2009) and canopy dieback (D. Schwilk,

2013, unpublished data). The increased tree mortality at higher elevations in CM is probably

217 related to the southerly exposure of the high elevation plots that were located on mesas of the

218 southeast rim at the edge of high elevation forest cover and the exacerbation of the drought

219 effects by the February freeze-thaw cycle. While high elevations of CM are cooler and more

220 humid than low elevations, the South Rim is exposed to high incident solar radiation due to its

221 southerly aspect, as well as high winds and temperature fluctuations because it forms the southern

222 edge of forest cover where the rim drops from $1981 \mathrm{~m}$ asl down to the desert floor. Higher 
223 elevations also probably experienced the lowest temperatures during the short-duration freeze

224 event in 2011, although cold air drainage also contributes to low temperatures at low elevations 225 (Schwilk, unpublished data). This may have stimulated greater damage to high elevation trees

226 through freezing-induced xylem cavitation in high elevation trees which may have let to higher 227 mortality during the course of the drought.

228 Conclusion

229

The results from this study demonstrate the impact of freeze-thaw events followed by

230 drought on Sky Island forest stand structure and species composition. Future acute drought events

231 are likely to occur with greater frequency as global mean temperatures rise in the coming

232 decades, and the climate becomes more unpredictable (Jentsch et al., 2007). Subsequent droughts

233 are likely to cause even greater damage to trees that survived this record drought in Texas,

234 especially if future drought events are coupled with severe freezes. Although I documented

235 significant rapid tree mortality in CM over the study period, lagged tree mortality is likely.

236 Delayed mortality has been observed elsewhere in response to severe drought (Pederson 1998;

237 Bigler et al., 2007), since damage to water transport tissue can occur over multiple years (Tyree

238 and Sperry, 1988; Hanson and Weltzin, 2000) and because tissue damage scan also predispose

239 trees to subsequent mortality from beetle infestations (Allen and Breshears, 1998). The dramatic

240 tree die off in CM in response to just one year of abnormal climatic conditions highlights the

241 need for long-term forest monitoring and studies that predict the effects of future climatic

242 extremes on Sky Island forests of the American Southwest.

\section{Acknowledgements}


244 The author thanks Richard Gatewood of the National Park Service for logistical assistance.

245 Darren Wallis, Peter Stothart, and Leslie Kuhn provided valuable field assistance for this project.

246 Financial support for this project was provided by the National Park Service as part of task \# $247 \mathrm{~J} 713005001 \mathrm{~K}$.

\section{References}

249 Allen, C. D. and D. D. Breshears. 1998. Drought-induced shift of a forest-woodland ecotone:

250 rapid landscape response to climate variation. Proc Natl Acad Sci USA 95, 14839-14842.

251 Allen, C. D., A. K. Macalady, H. Chenchouni, D. Bachelet, N. McDowell, M. Vennetier, T. Kitzberger, A. Rigling, D. D. Breshears, E. H. Hogg, P. Gonzalez, R. Fensham, Z. Zhang, J. Castro, N. Demidova, J. H. Lim, G. Allard, S. W. Running, A. Semerci, and N. Cobb. 2010. A global overview of drought and heat-induced tree mortality reveals emerging climate change risks for forests. Forest Ecology and Management 259, 660-684.

Akaike, H. 1974. A new look at the statistical model identification. Automatic Control, IEEE Transactions 19(6), 716-723.

Bates, D. M. 2010. Lme4: Mixed-effects modeling with R. URL http://lme4. r-forge. r-project. org/book.

Bigler, C., D. G. Gavin, C. Gunning, and T. T. Veblen. 2007. Drought induces lagged tree mortality in a subalpine forest in the Rocky Mountains. Oikos 116(12): 1983-1994.

Bowker, M. A., A. Munoz, T. Martinez, and M. K. Lau. 2012. Rare drought-induced mortality of 
265 Breshears, D. D., N. S. Cobb, P. M. Rich, K. P. Price, C. D. Allen, R. G. Balice, W. H. Romme, J.

266 H. Kastens, M. L. Floyd, J. Belnap, J. J. Anderson, O. B. Myers, and C. W. Meyer. 2005.

267 Regional vegetation die-off in response to global-change-type drought. Proceedings of the

268 National Academy of Sciences of the United States of America 102, 15144-15148.

269 Breshears, D. D., O. B. Myers, C. W. Meyer, F. J. Barnes, C. B. Zou, C. D. Allen, N. G.

270 McDowell, and W. T. Pockman. 2009. Tree die-off in response to global change-type

271 drought: mortality insights from a decade of plant water potential measurements.

$272 \quad$ Frontiers in Ecology and the Environment 7,185-189.

273 Carter, W. T. 1928. Soil survey (reconnaissance) of the Trans-Pecos area, Texas. Bulletin of the $274 \quad$ University of Texas Soil Service 35,1-66.

275 National Drought Mitigation Center. 2011. US Drought Monitor.

276 Davis, S. D., J. S. Sperry, and U. G. Hacke. 1999. The relationship between xylem conduit diameter and cavitation caused by freezing. American Journal of Botany 86,1367-1372.

278 Ganey, J. L. and S. C. Vojta. 2011. Tree mortality in drought-stressed mixed-conifer and 279 ponderosa pine forests, Arizona, USA. Forest Ecology and Management 261, 162-168.

280 Gitlin, A. R., C. M. Sthultz, M. A. Bowker, S. Stumpf, K. L. Paxton, K. Kennedy, A. Munoz, J. K. Bailey, and T. G. Whitham. 2006. Mortality gradients within and among dominant plant populations as barometers of ecosystem change during extreme drought.

284 Guarin, A. and A. H. Taylor. 2005. Drought triggered tree mortality in mixed conifer forests in 285 Yosemite National Park, California, USA. Forest Ecology and Management 218,229-244.

286 Hammel, H. T. 1967. Freezing of Xylem Sap without Cavitation. Plant Physiology 42, 55-\&. 
287 Hogg, E. H., J. P. Brandt, and M. Michaellian. 2008. Impacts of a regional drought on the 288 productivity, dieback, and biomass of western Canadian aspen forests. Canadian Journal 289 of Forest Research-Revue Canadienne De Recherche Forestiere 38, 1373-1384.

290 Jentsch, A., J. Kreyling, and C. Beierkuhnlein, C. 2007. A new generation of climate-change 291 experiments: events, not trends. Frontiers in Ecology and the Environment, 5(7), 365-374.

292 Kuznetsova, A. 2013. ImerTest: tests for random and fixed effects for linear mixed effect models $293 \quad$ (lmer objects of lme4 package).

294 Lajtha, K. and J. Getz. 1993. Photosynthesis and Water-Use Efficiency in Pinyon-Juniper 295 Communities Along an Elevation Gradient in Northern New-Mexico. Oecologia 94, 95296101.

297 Linton, M. J., J. S. Sperry, and D. G. Williams. 1998. Limits to water transport in Juniperus 298 osteosperma and Pinus edulis: implications for drought tolerance and regulation of 299 transpiration. Functional Ecology 12, 906-911.

300

Lopez, O. R. and T. A. Kursar. 2007. Interannual variation in rainfall, drought stress and seedling 301 mortality may mediate monodominance in tropical flooded forests. Oecologia 154, 35-43.

302 Lorimer, C. G., S. E. Dahir, and E. V. Nordheim. 2001. Tree mortality rates and longevity in 303 mature and old-growth hemlock-hardwood forests. Journal of Ecology 89, 960-971.

304 McDowell, N., W. T. Pockman, C. D. Allen, D. D. Breshears, N. Cobb, T. Kolb, J. Plaut, J.

305 Sperry, A. West, D. G. Williams, and E. A. Yepez. 2008. Mechanisms of plant survival 306 and mortality during drought: why do some plants survive while others succumb to 307 drought? New Phytologist 178, 719-739. 
308 Mendel, Z., F. Assael, N. Saphir, A. Zehavi, D. Nestel, and G. Schiller. 1997. Seedling mortality 309 in regeneration of Aleppo pine following fire and attack by the scale insect Matsucoccus $310 \quad$ josephi. International Journal of Wildland Fire 7, 327-333.

311 Mueller, R. C., C. M. Scudder, M. E. Porter, R. T. Trotter, C. A. Gehring, and T. G. Whitham. 312 2005. Differential tree mortality in response to severe drought: evidence for long-term 313 vegetation shifts. Journal of Ecology 93, 1085-1093.

314 Muldavin, E. H. 2002. Some floristic characteristics of the northern Chihuahuan Desert: a search 315 for its northern boundary. Taxon 51, 453-462.

316 National Drought Mitigation Center. 2011. U. S. Drought Monitor. Retrieved from

317 http://droughtmonitor.unl.edu/MapsAndData/GISData.aspx

318 Neilsen-Gammon, J. W. 2011. The 2011 Texas Drought; A Breifing Package for the Texas 319 Legislature. Page 43. Office of the State Climatologist.

320 Neilson, R. P. and L. H. Wullstein. 1985. Comparative Drought Physiology and Biogeography of 321 Quercus-Gambelii and Quercus-Turbinella. American Midland Naturalist 114, 259-271.

322 Palahi, M., T. Pukkala, J. Miina, and G. Montero. 2003. Individual-tree growth and mortality 323 models for Scots pine (Pinus sylvestris L.) in north-east Spain. Annals of Forest Science $32460,1-10$.

325 Pedersen, B. S. 1998. The role of stress in the mortality of Midwestern oaks as indicated by 326 growth prior to death. Ecology 79: 79-93.

327 Pinheiro, J. C. and D. M. Bates. 2000. Mixed-effects models in S and S-PLUS. New York, 328 Springer: xvi, $528 \mathrm{p}$. 
329 Pittermann, J., J. S. Sperry, U. G. Hacke, J. K. Wheeler, and E. H. Sikkema. 2005. Torus-margo 330 pits help conifers compete with angiosperms. Science 310, 1924-1924.

331 Poulos, H. M. and G. P. Berlyn. 2007. Variability in needle morphology and water status of Pinus 332 cembroides across an elevational gradient in the Davis Mountains of west Texas, USA. 333 Journal of the Torrey Botanical Society 134, 281-288.

334 Poulos, H. M. and A. E. Camp. 2010. Topographic influences on vegetation mosaics and tree 335 diversity in the Chihuahuan Desert Borderlands. Ecology 91, 1140-1151.

336 Poulos, H. M., U. M. Goodale, and G. P. Berlyn. 2007. Drought response of two Mexican oak 337 species, Quercus laceyi and Q-sideroxyla (Fagaceae), in relation to elevational position. American Journal of Botany 94, 809-818.

Powell, A. M. 1998. Trees and Shrubs of the Trans Pecos. Big Bend Natural History Association, 340 Big Bend National Park.

341 R Development Core Team. 2013. A language and environment for statistical computing. Vienna, $342 \quad$ Austria, R Foundation for Statistical Computing.

343 Scholander, P., E. Hemmingsen, and W. Garey. 1961. Cohesive Lift of Sap in Rattan Vine 344 Problem of How Sap Rises Lies Stranded for Lack of Means to Measure Negative $345 \quad$ Pressure in Liquids. Science 134,1835.

346 Shaw, J. D., B. E. Steed, and L. T. DeBlander. 2005. Forest Inventory and Analysis (FIA) annual 347 inventory answers the question: What is happening to pinyon-juniper woodlands? Journal 348 of Forestry 103, 280-285.

349 Sperry, J. L. 2011. Is Mortality All It's Cracked Up to Be After Injury? Archives of Surgery 146, $350 \quad 200-200$. 
351 Sperry, J. S., K. L. Nichols, J. E. M. Sullivan, and S. E. Eastlack. 1994. Xylem Embolism in

352

353

354

355

356

357

358

359

360

361

362

363

364 365

366

367

368

369

370

Ring-Porous, Diffuse-Porous, and Coniferous Trees of Northern Utah and Interior Alaska. Ecology 75, 1736-1752.

Sperry, J. S. and J. E. M. Sullivan. 1992. Xylem Embolism in Response to Freeze-Thaw Cycles and Water-Stress in Ring-Porous, Diffuse-Porous, and Conifer Species. Plant Physiology $100,605-613$.

Sperry, J. S. and M. T. Tyree. 1990. Water-Stress-Induced Xylem Embolism in 3 Species of Conifers. Plant Cell and Environment 13, 427-436.

Sucoff, E. 1969. Freezing of Conifer Xylem and Cohesion-Tension Theory. Physiologia Plantarum 22, 424-431.

Tardieu, F. and T. Simonneau. 1998. Variability among species of stomatal control under fluctuating soil water status and evaporative demand: modelling isohydric and anisohydric behaviours. Journal of Experimental Botany 49, 419-432.

Tyree, M. T., and J. S. Sperry. 1989. Vulnerability of xylem to cavitation and embolism. Annual review of plant biology, 40, 19-36.

van Mantgem, P. J., N. L. Stephenson, J. C. Byrne, L. D. Daniels, J. F. Franklin, P. Z. Fule, M. E. Harmon, A. J. Larson, J. M. Smith, A. H. Taylor, and T. T. Veblen. 2009. Widespread Increase of Tree Mortality Rates in the Western United States. Science 323, 521-524.

Vandevender, T. R. and W. G. Spaulding. 1979. Development of Vegetation and Climate in the Southwestern United-States. Science 204, 701-710.

371 West, A. G., K. R. Hultine, J. S. Sperry, S. E. Bush, and J. R. Ehleringer. 2008. Transpiration and 372 hydraulic strategies in a pinon-juniper woodland. Ecological Applications 18, 911-927. 
373 Willson, C. J. and R. B. Jackson. 2006. Xylem cavitation caused by drought and freezing stress in 374 four co-occurring Juniperus species. Physiologia Plantarum 127, 374-382.

375 Western Regional Climate Center. 2013. Cooperative Climatological Data Summaries. Retrieved 376 from http://www.wrcc.dri.edu/climatedata/climsum/

377 Zimmermann, M. H. 1983. Xylem structure and the ascent of sap. Springer, Berlin. 


\section{Table 1 (on next page)}

mortality by elevation

Table 1: Changes in live tree density $\left(\mathrm{ha}^{-1}\right)$ between 2009 and 2011 in the Chisos Mountains of Big Bend National Park, Texas. Values are reported as means ( + S. E.). 
Table 1: Changes in live tree density $\left(\mathrm{ha}^{-1}\right)$ between 2009 and 2011 in the Chisos Mountains of Big Bend National Park, Texas. Values are reported as means ( \pm S. E.).

\begin{tabular}{ccccc}
\hline elevation & $\begin{array}{c}\text { live trees pre } \\
\text { drought }\end{array}$ & live trees post-drought & $\begin{array}{c}\text { change in live tree } \\
\text { density }\end{array}$ \\
\hline Low & $236.6 \pm 41.6$ & $146.7 \pm 29.1$ & $127.3 \pm 23.9$ \\
midddle & $605.1 \pm 100.0$ & $483.3 \pm 100.0$ & $132.7 \pm 60.8$ \\
High & $748.4 \pm 142.0$ & $502.0 \pm 150.0$ & $296.2 \pm 82.3$ \\
\hline
\end{tabular}




\section{Figure 1}

climate

Figure 1: Climatic conditions from 2010-2012 in the Chisos Basin of Big Bend National Park, Texas (WRCC 2013) including A) monthly extreme low temperatures, B) mean monthly maximum temperatures, and C) mean monthly precipitation. The weather station is located within $0.25 \mathrm{~km}$ of the middle elevation sample sites in this study. 

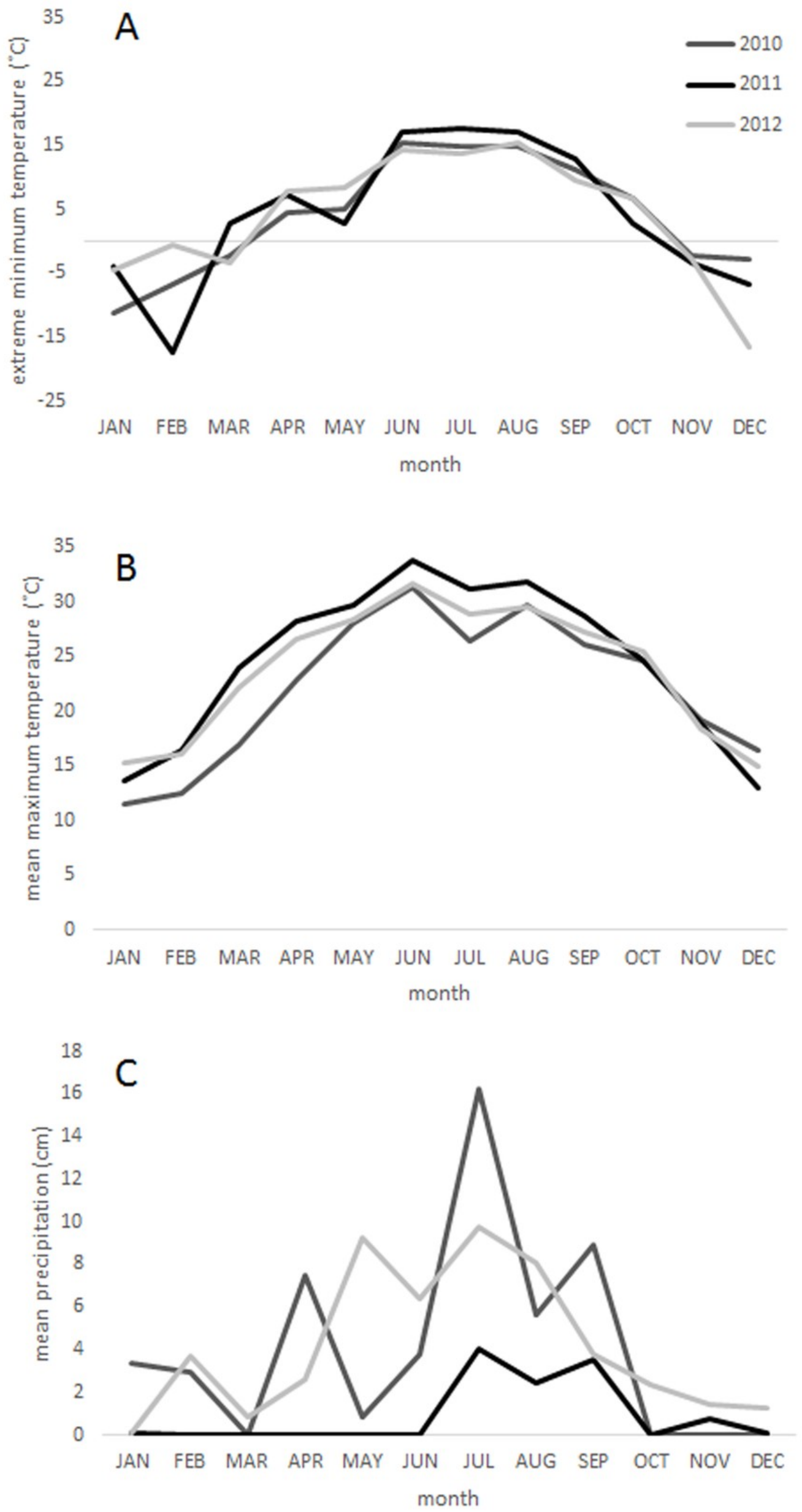


\section{Figure 2}

stand structural change

Figure 2: Changes in forest stand structure due to drought and freezing in 2011 in the Chisos Mountains, Big Bend National Park, Texas. Mean values (+ S. E.) prior to the drought (2009) and after the drought (2011) are shown for A) seedlings by species, B) live trees ( $>5 \mathrm{~cm}$ $\mathrm{dbh}$ ) by species, C) live trees in $5 \mathrm{~cm}$ diameter classes, and D) standing dead trees.

Significant changes between sampling intervals $(P<0.05)$ are indicated with an $\left({ }^{*}\right)$. Species codes are as follows: arxa = Arbutus xalapensis, cuar $=$ Cupressus arizonica, frgr $=$ fraxinus greggii, jufl = Juniperus flaccida, jude $=$ Juniperus deppeana, jumo = Juniperus monosperma, pice $=$ Pinus cembroides, $\mathrm{prgl}=$ Prosopis glandulosa, quar $=$ Quercus arizonica, quem $=$ Quercus emoryi, qugrav = Quercus gravesii, qugri = Quercus grisea, qupu $=$ Quercus pungens.
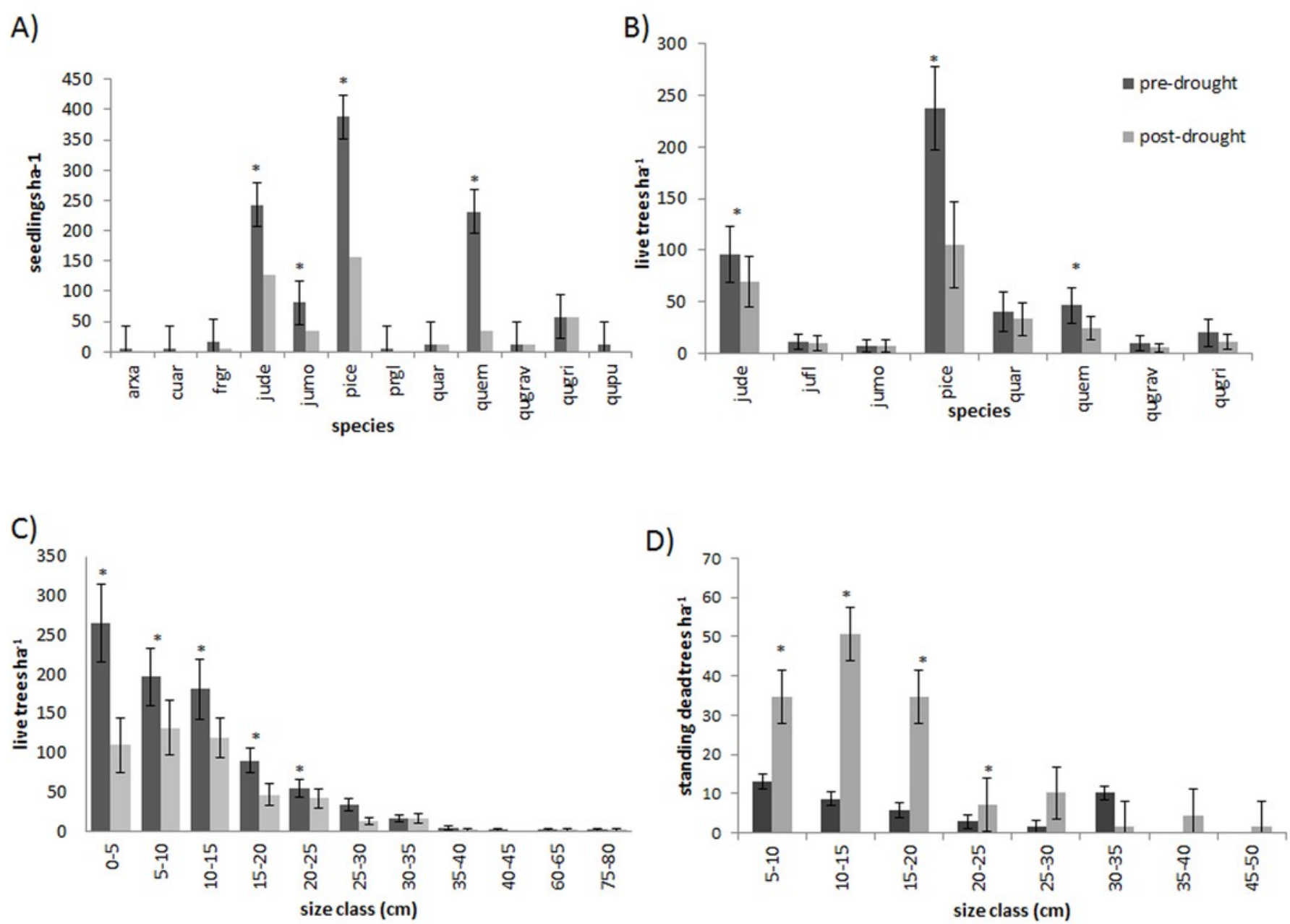


\section{Figure 3}

regressio

Figure 3: Regression of tree $\mathrm{dbh}(\mathrm{cm})$ as a predictor of percentage tree mortality. Percentage mortality was significantly $(P=0.0016)$ correlated with tree size $(y=9.9538 e-0.062 x)$. Smaller trees suffered 2 to 5 times higher mortality than larger trees.

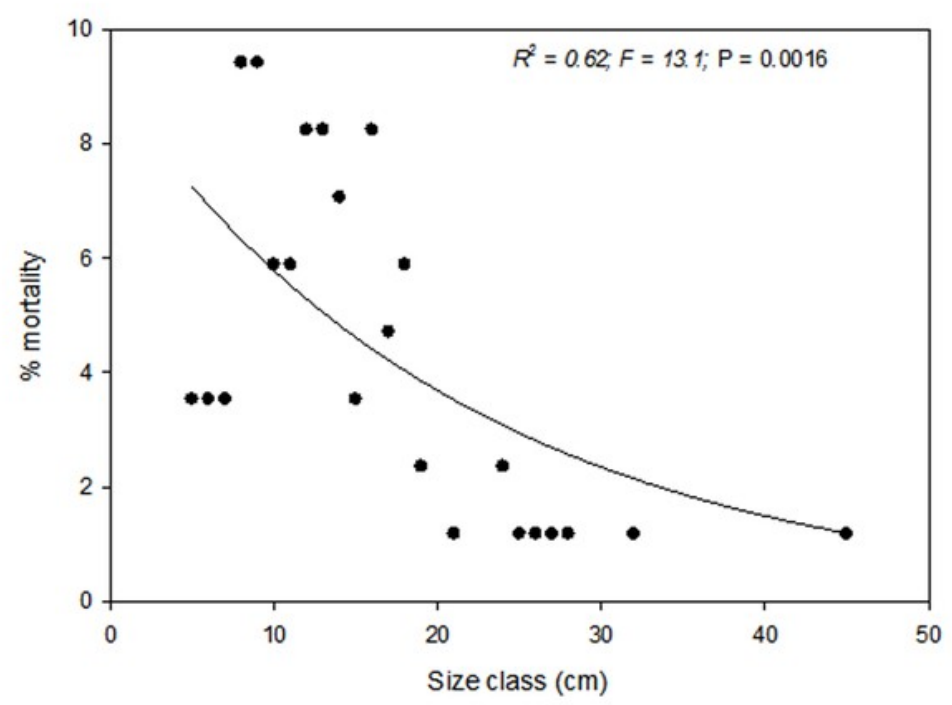




\section{Figure 4}

elevation mortality

Figure 4: Changes in mean (+ SE) live tree density (ha-1) at low, middle, and high elevations of the Chisos Mountains, Texas. Significant changes between sampling intervals $(P<0.05)$ are indicated with an $\left(^{*}\right)$.

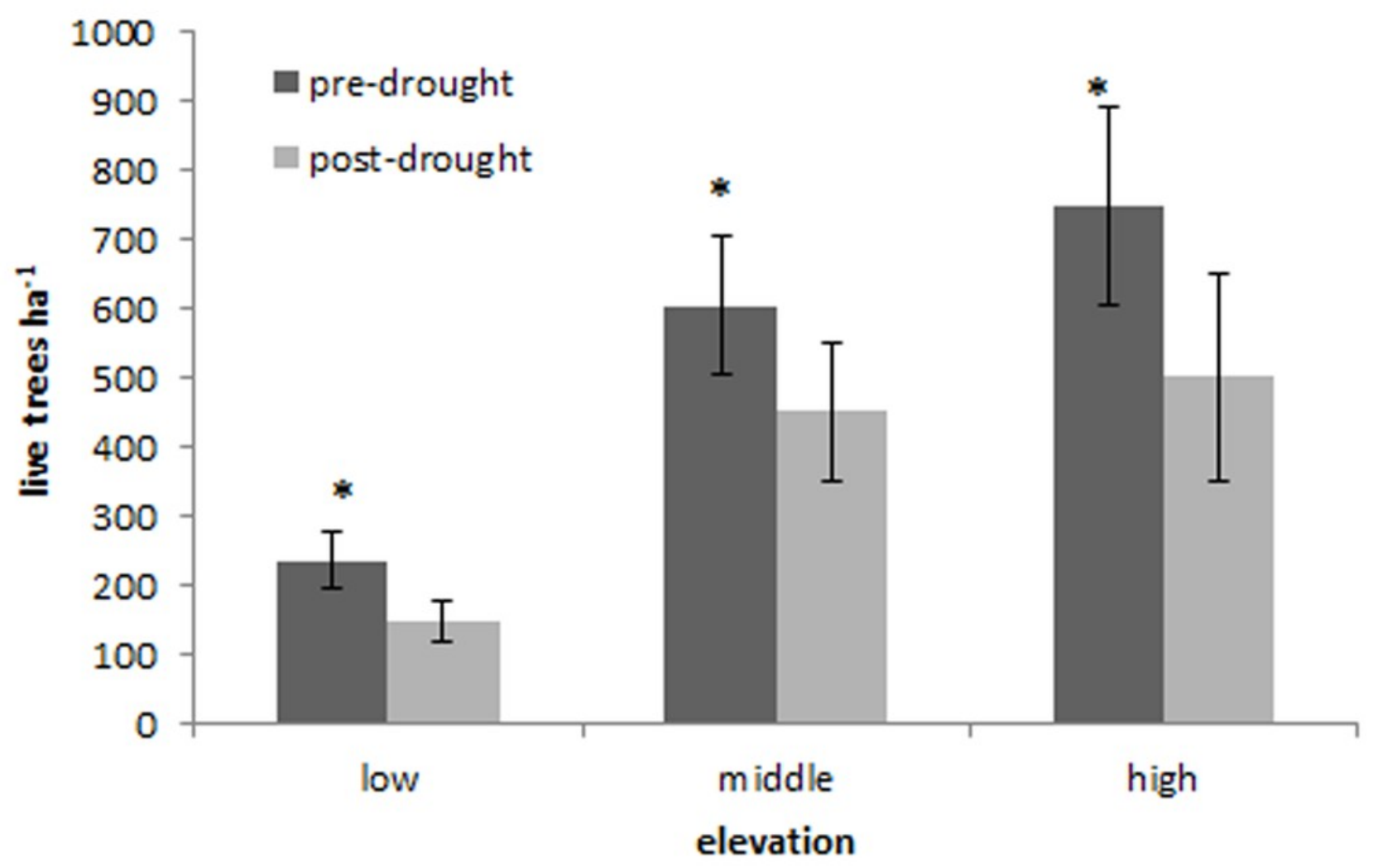

